\title{
THE ETHNIC TURKISH MINORITY IN WESTERN THRACE, GREECE
}

\author{
TÜRKKAYA ATAÖV
}

\section{Introduction:}

In Greece there is an ethnic Turkish minority, ${ }^{1}$ whose religious affiliation is Islam. The Turks are the most numerous (about 130,000 ) among the minorities in Greece although they are not the only one. ${ }^{2}$ The ethnic Turks are concentrated in a small (8578 sq. km.) Balkan territory called 'Western Thrace', which is bordered on the east by Turkey, on the west by the Greek part of Macedonia, on the north by Bulgaria and on the south by the Aegean Sea. The area stretches from the Maritza (Meriç) river in the east as far as the Mesta (Karasu) river in the west. The region includes the Rhodope mountains in the north. The Maritza river divides modern Thrace into the 'Eastern' (or Turkish) and the 'Western' (or Greek) portions. A part of Thrace is, then, within the borders of European Turkey.

\footnotetext{
${ }^{1}$ The terms 'ethnic Turkish minority', 'Turkish community' and 'Muslim Turks' will be used in this text to designate the Turks of Western Thrace in Greece. An overwhelming majority of the Turks are Islamic while not all but again the majority of the Muslims there are Turks. The rest of the Muslims are Pomaks and Roma (Gypsies) with a small number of Circassians (Cherkez), just as there are also a small group of Christian Turks (Gagauz), who congregate mainly in the northern parts of the Balkans.

${ }^{2}$ Apart from the Muslim and Christian Turks, Greece has (Slav) Macedonians, (Muslim) Pomaks, (Muslim) Circassians, (Muslim) Albanians (of Camuria), (Christian) Albanians, (Christian and Latin-speaking) Vlahs (Koutsvlahs or Aromani), Jews, Armenians and others. Türkkaya Ataöv, "The Ethnic Minorities of Greece," A.Ü. Siyasal Bilgiler Fakūltesı Dergísi, 46/3-4 (1991), 15-33.
} 
The Turks have been living in both sides of Thrace since the mid-14th century. They constitute the whole of the population in the eastern part, and used to make the majority in the west as well until the 1920s. The Ottoman Empire abandoned Western Thrace to Bulgaria, in accordance with the 1913 Treaty of Istanbul, Greece annexed it in 1920 under the Treaty of Sèvres. The Treaty of Lausanne (24 July 1923), which opened up a new era in Turkish history, ceded the region to the Greeks. Under a protocol of the same year, Greece and Turkey decided on a compulsory exchange of Greek and Muslim minorities in each other's country with two exceptions. ${ }^{3}$ The exceptions were the Greeks of Istanbul, who formed a minority there and the Muslims of Western Thrace, who composed the majority then. The Turkish community outnumbered the Greek four to one. It had been on this basis that the first 'Turkish republic' in history, in the form of a 'Western Thracian Provisional Government' was formed in 1913.4 The Turks not only outnumbered the Greeks, but also owned most (close to 84 percent) of the land. Had there been no steady outflow, since 1923 , of the Turkish population, the number would have reached perhaps half a million today. For the last eight decades, a few hundred-thousand Turks, who have a high rate of population growth, left Western Thrace, mostly going to Turkey. It is on account of constant migration that their number has stayed the same and that they have lost property, now owning a third of the land. ${ }^{5}$

Western Thrace presently contains three administrative provinces: Xanthi with capital Xanthi (Iskece); Rhodope with capital Komotini (Gümülcine); and Evros with capital Alexandroup (Dedeağaç). The Turks living there, now reduced to a minority, on account of migrations, strippings of citizenship and new Greek settlements, do not represent a separatist

${ }^{3}$ For a Greek source on the exchange of populations and other agreements between Greece and Turkey that followed Lausanne, see: Dimitri Pantzopoulos, The Balkan Exchange of Minorities and Its Impact Upon Greece, The Hague, 1962. A Turkish source: T.C., Hariciye Vekâleti, Lozan Konferansı: 1922-1923, Istanbul, 1340. 1924.

${ }^{4}$ A Turkish source on the establishment of a Turkish republic in Western Thrace: Ahmet Kayıhan, Lozan ve Batı Trakya: 1913'de Ilk Türk Cumhuriyeti, Istanbul, 1967.

${ }^{5}$ The Turkish delegation at Lausanne stated that the Turks in Western Thrace Were 129,120 (67 percent) and the Greeks 33,910 (18 percent). The Greeks claimed that the Turks were slightly above 100,000, but nevertheless constituting the overwhelming majority. The Turks also insisted that they owned most of the land while the Greeks, being largely traders, possessed only five percent. The Greeks contested these figures as well, admitting, however, that most of the land belonged to the Turks. Great Britain, Cmd. 1814, Turkey No. 1 (1923). Lausanne Conference on Near Eastern Affairs, London. 
movement but have been asserting for decades that the policy of the Greek Government was one of deliberate discrimination with a long-term aim of assimilation. Over the years, the Turks have complained of denial of ethnic identity, discrimination and abuse of human rights. ${ }^{6}$ It is only recently that non-Turkish sources have come to recognize the restrictions on the lives of the Turks and the degrading treatment accorded to them. ${ }^{7}$ For decades, the Greek public and the government stood unmoved to the cries of the Turkish minority for justice. ${ }^{8}$ The government started taking some steps in mid-1991

${ }^{6}$ Two Turkish sources: Halûk Bayülken, "Turkish Minorities in Greece", Turkish Yearbook of International Affairs: 1963, Ankara, Faculty of Political Science, 1965, pp. 145-164; Baskın Oran, TürkYunan Ilişkilerinde Batı Trakya Sorunu, Ankara, Mulkiyeliler Birliği Vakfı, 1986.

${ }^{7}$ For a long time it was assumed that Greece, being the 'cradle of Western civilization', could not possibly mistreat its own minorities and that discussions of democracy ought to stop at the borders of this country. For instance, The Economist of London mentioned several Balkan minorities but failed to report on the Turks, Macedonians and the Albanians of Greece. For my reply, see: The Economist, 22 June 1985, 6. Authoritative works came in the 1980s: Hugh Poulton, The Balkans, London, Minority Rights Group, 1991; Helsinki Watch, Destroying Ethnic Identity: the Turks of Greece, New York, 1990; Minority Rights Group, Minorities in the Balkans, London; Fred De Jong. $\mathrm{Names,}$ Religious Denomination and Ethnicity of Settlements in Western Thrace, Leiden, E.J. Brill, 1980; "The Muslim Minority in Western Thrace", pp. 95-100, in G. Ashworth, ed., World Minorities in the Eighties, London; Iwao Kamozawa, The Case of Turks in Western Thrace, Tokyo, Mediterranean Studies Research Group, Hitotsubashi University, 1982; Bjorn Cato Funnemark, The Turkish Minority in Greece, tr. by Arne Bakke, Oslo, the Norwegian Helsinki Committee, 1991. Professor Erik Siesby made the following statement at the Conference in the Folketinget, Denmark (1990): "In Greece the Turkish minority is much too small to present any danger to the society. The treatment of this population as second class citizens has harmed, not only the ethnic Turks, but even more the reputation of Greece as a civilized society." Minority Rights Group, Minority Rights in Europe, London, 1990.

${ }^{8}$ K.G. Andreades, a Greek writer, formerly an officer of the jendarmerie in Western Thrace, asserts that Greece "protected and still protects, in the best way possible, the Muslims living within its boundaries". He ends his book with the following conclusion: "It can also be taken for granted that there need be no fear for the Moslems of Cyprus when this island comes to be united again with Greece". K.G. Andreades, The Moslem Minority in Western Thrace, Thessaloniki, Institute for Balkan Studies, 1956; Amsterdam, Adolf M. Hakkert, 1980, p. 59. Another Greek author tries to link Turkey's interest in the Turks of Western Thrace to "Turkish irredentism". Paul Hıdıroğlou, Western Thrace in the Light of the National Ideal of the Turks, Athens, Herodotos, 1990. On the other 
to improve conditions for the Turks, who nevertheless still face important problems.

\section{Legal Guarantees and Positive Steps:}

The Greek Government's obligations to guarantee the rights of the Turkish community stems from a number of treaties and agreements. According to Articles 37-45 of the Treaty of Lausanne (1923), the Greek and the Turkish governments are obliged to protect the respective minorities in their territories. They agreed to provide equality before the law, protection of life and liberty, free use of any language, free exercise of religion, the right to establish and control their own institutions and schools, the right to give instruction in their own languages, freedom of movement and all other rights enjoyed by the majority. To be more precise, all these guarantees were mentioned (in Articles 37-44) in respect to the Greek minority in Istanbul and the last one (Article 45 ) shortly but equally bindingly stated that the same rights were recognized by Greece in relation to its Muslim minority. The safeguards under the Lausanne Treaty were mainly political and cultural, the Greek minority in Turkey being generally well off economically The Turkish minority in Western Thrace, on the other hand, needed, not only political and cultural protection, but also economic safeguards. In any case, not even the former was observed to the extent of denying the existence of an ethnic Turkish community.

Although the Lausanne text employed the term 'Muslim', what was meant, in terms of Greece's relations with Turkey, was the Turks, as many other successive documents identified them as such. For instance, the Greek and the Turkish governments signed (1968) a protocol guaranteeing that each country would respect the ethnic and religious consciousness of the Greek and Turkish minorities. Greece also signed a number of intemational documents, including the European Convention for Human Rights, which establishes broad guarantees for fundamental freedoms. The Helsinki Final Act (1975) specifically requires the signatories to respect the rights of national minorities. Further, the documents of the follow-up meetings of the Conference on Security and Cooperation in Europe (CSCE) ensure the rights of the same.

The Greek Constitution also protects the rights of the Turkish minority in Western Thrace. According to the letter of the constitution, all citizens are equal before the law, withdrawal of Greek citizenship is permitted

hand, a five-page report, issued by a group of Greak scientists, representing the Greek Greens Party and led by Panayotis Dimitros, an academics from the Economic Faculty in Athens, recognized that Greece was discriminating against the Turkish community. Reported in the Turkish Daily News, Ankara, 25 July 1990. 
only in voluntary acquisition of another citizenship or in case of acts contrary to national interests, all persons enjoy full protection of their life, honor and freedom, measures restrictive of free movement are prohibited, and the press is free.

But in spite of these international and national guarantees, the Turkish minority is suffering from serious human rights abuses. The Greek government has allowed ethnic Turks, since 1991, to buy or sell land and houses, repair dwellings and mosques, obtain licenses for tractors, trucks and cars, and open shops. None of these was possible until very recently. Prime Minister Constantine Mitsotakis went to Western Thrace in May 1991 and admitted that mistakes had been made in the past. Some of these errors have been corrected, but other blunders still continue.

\section{Continuing Problems:}

The core of the conflict is that the Greek Government denies even the existence of an ethnic Turkish minority and moreover subjects it to a degrading treatment in a number of ways. Although the Turks living there are the sons and daughters of Turkish-speaking people who settled centuries ago, the Greeks refer to them as 'Hellenic Muslims', which is an inept and misleading description. A great majority of them are Muslims in terms of religion, which was a criterion for identification, in accordance with Islamic law and practice. The Turks, however, also have a national or ethnic identity, just like the other Muslims in Greece, such as the Pomaks or even the nonMuslims like the Vlahs.

There were brief times when the Turkish identity was recognized. Two orders, dated 1954 and 1955 and signed by the (Greek) Chief Administrator of Thrace, pursuant to the instructions of the Prime Minister, asked all concerned to use the terms of 'Turk' or 'Turkish', instead of 'Muslim'. 9 For some time, protocols for educational programs referred to Turkish schools', old photographs showed inscriptions on the buildings as Turkish elementary school', diplomas identified the holder as 'Turk', and some textbooks were described as 'Turkish books'.

The change occurred later, especially after the communiqué of the president of the Greek Parliament, dated 10 October 1985, in which he stated that the term 'Greek Muslims' must henceforth be used. The Greek courts effectively outlawed the use of the word 'Turkish'. Officials conformed to the order first by removing all signs which carried that word. It culminated with the arrest and imprisonment of two Turkish candidates (Dr. Sadık Ahmet and Ismail Şerif), who ran in elections (of June and November 1989) for the Greek Parliament and who by name referred to the Turkish minority. They

\footnotetext{
${ }^{9}$ Andreades, op. cit., 14-15.
} 
were charged with violating the Penal Code (Article 192) by 'openly and indirectly inciting citizens to violence or creating rifts among the population at the expense of social peace' simply by the use of the word 'Turkish'. Their trial, filmed by the Dutch TV, was a political demonstration, after which mobs of Greeks attacked Turkish shops and offices and beat ethnic Turks. Several foreigners and Greeks concurred that not a single Christian-owned premises was attacked, and that there was little or no police intervention. ${ }^{10}$

It is still illegal in Greece for a Turkish association to be called Turkish'. Youth and professional organizations, the few that used to exist, were all closed down by the order of the courts for having that name in their titles.

The freedom of expression of the Turks are also violated. The Turkish minority brings out single-sheet newspapers (like Dr. Ahmet's Balkan) in Turkish, but similar publications printed in Turkey are not allowed entry into Western Thrace, and propriators or writers are too often punished either by imprisonment or heavy fines for articles critical of the Greek Government. Turkish TV and at times Turkish radio broadcasts are jammed. Even in 1992 a press conference by the Greek section of the London-based Minority Rights Group was banned at government instigation. ${ }^{11}$

The three chief problem areas in education, which is of great concem to the Turkish community, are textbooks, teachers and lack of place in secondary schools for Turkish children. Generations of young Turks have been using the same obsolete educational material, with pages torn or missing. The 1968 protocol allows Turkey to send schoolbooks, which are held up by the Greek officials. The Turkish minority objected to the use of a Turkish language book, prepared by the Greek Government.

The Turkish teachers often have difficulty in obtaining permits from the Greek Embassy in Ankara. The Greek teachers offer courses in ancient Greek, Greek language, history, sociology and related subjects, and the children consequently follow only half of the program, teachers from Turkey not being available. Local Turks, with degrees in teaching from Turkey are generally not allowed to fill the vacancies although their salaries are met by the Turkish community. The non-Turkish teachers, trained in a special school in Thessaloniki, are either selected among the Pomaks of from people who are either unqualified or know little Turkish.

There are not enough places in the Turkish high schools for all who wish to pursue further education. The Turkish community cannot get the

${ }^{10}$ Athens News, 4 and 10-11 February 1990.

${ }^{11}$ The Financial Times, 2 February 1992. 
permission to build new schools or use the existing empty space. According to a protocol (1952), reflected in Greek law no. 2203, the director of the (Turkish) Celâl Bayar High School has to be Turkish. The present one is Greek. Since an entrance examination in Greek determines who will be enrolled in the two Turkish secondary schools, many youngsters prefer to go Turkey to pursue education. There is a suspicion that the Greek Government wants the young Turks to go to Turkey because most of them may not come back and eventually draw their families as well. In any case, their diplomas are not officially recognized when they retum to Greece. Or they might loose their citizenship altogether.

The notorious Article 19 of the Greek Nationality Law (1955) states that "a person of non-Greek ethnic origin leaving Greece without the intention of returning may be declared as having lost Greek nationality..." This article, amply applied in the past in the case of the Turks and still in use, violates the Greek Constitution (Article 4) and the Concluding Document of the Vienna Follow-up Meeting to the CSCE (1989). Those Turks who go abroad to study or their parents who leave the Greek soil to visit their sons and daughters where they receive their education find out, while trying to return, that they have lost their citizenship. Police merely asks the opinion of the neighbors if the Turks in question intend to return or not. If one of the replies is 'no', then, a note to the Ministry of Interior leads to the cancellation of his citizenship, without even notifying the person. There are even cases of those who lost their citizenship while away doing military service. There is no judicial review, and appeals are expensive and time-consuming.

The Greek Government restricts the freedom of movement of the Turks by seizing their passports. Such confiscation, without a hearing and a right of judicial review, violates the Greek Constitution and the international agreements which Greece has signed. The freedom of movement of the Turks is further hindered on the basis of the so-called 'restricted military areas', i.e., land bordering on Bulgaria, where the inhabitants may move only as far as 30 kilometers from their dwellings and where the whole area is closed anyway between midnight and 5:00 a.m.

The Turks generally face a degrading treatment. The Greek police frequently harasses them and outside observers who try to help them. Lawyers who represent the Turkish minority are often called in for interrogation, their passports are confiscated, their homes are watched and foreigners who investigate this situation also become targets, involving beatings by the police and the mob. Such harassment has lessened, but still exists.

Ethnic Turks are discriminated against in employment and in the provision of services. They come up to special difficulties especially in civil 
service appointments, very few and low level of which go to the Turks. They are deprived of certain public services, such as obtaining private telephones, which are readily available to the Greeks.

The government awards free land to some Greek Christians. The lands of the Turks, on the other hand, are frequently confiscated. Although land is so important in this farming area, it has been seized a number of times, allegedly to build the University of Thrace or an open-air prison, but only a small portion has been used as school buildings. The Turks loose more fertile land at a significantly faster rate. This comparison is more distressing for the Turks since they are dependent on agriculture. In some instances, as evident in the Inhanlı (Evlalon) case in the Xanthi district, the Greek courts frequently rule that the Turkish farmers are 'unlawful interferents' and the land in question is not returned to their owners in spite of the over-ruling decision of a higher court. 12

Although all Greek citizens have the right to vote in elections, justice has not been done to the Turks in this respect as well. In several recent parliamentary elections the Turkish-Greek border was closed to bar those Turks returning to Greece from casting their vote; bus service to Western Thrace was cancelled, and air connection blocked; Greek soldiers were brought in from other parts of the country to outweigh the ethnic Turks; the number of ballot boxes diminished from one election to another; ethnic Turks were not allowed to vote until late in the afternoon; polling stations in Turkish areas were closed early; vote totals were not announced in some areas; no votes at all for Turkish candidates were listed in such a Turkish stronghold as the village of Sofular, and the applications of the Turkish candidates were rejected in the wake of the elections.

The Turks are also no longer able to elect their own muftis, or religious leaders. The Treaty of Lausanne provides for the free exercise of religion, including the selection of muftis. The Greek Law No. 2345 (1920) also states that the denominational heads must be elected by the respective communities. And the CSCE documents recognize religious freedom for the minorities. There are three muftis in Eastern Thrace, one for each administrative district. Following the death of the Komotini mufti (1985), the Greek authorities appointed a new one without consulting its Muslim citizens. A new law (No. 1920, 1990) further announced that the muftis would henceforth be appointed by the government for ten years. The Turkish minority, nevertheless, elected its own muftis, creating in each community pairs, one appointe $d$ and the other democratically elected. The former is paid

${ }^{12}$ Baskin Oran, "The Inhanlı Land Dispute and the Status of the Turks in Western Thrace", Journal, London, Institute of Muslim Minority Affairs, 9/2 (1984), 360-370. 
by the government, and the latter supported financially by the community. When the Muslim Turkish community held a demonstration (1991) in Xanthi to protest the new law, the Greeks attacked Turkish dwellings and shops, the police doing virtually nothing to stop them.

The Turks are not allowed to control their own charitable foundations (waqfs). The Treaty of Lausanne and the CSCE documents provide that minorities shall have the right to establish, maintain and control their educational, cultural and religious institutions. Although the directors of the waqfs were elected by the community before the military junta (1967), Greek law No. 1091 (1980) brought the practice of a board of five administrators, selected by the Greek nomarch. The latter are the real administrators although the appointed muftis seem to be technically involved.

Being religious endowments supported by the local people, the waqfs are also expected to be in charge of Muslim Turkish architectural heritage in Greece. ${ }^{13}$ The heritage in question is the immovable cultural works of a civilization that played an important role in an area on which there are now 24 nation-states. It is, in fact, a mutual heritage fostered by local variations. For the Turks, it is a part of their cultural identity. Bu in Greece, the Ottoman Empire is generally considered as non-existent. The terms "postByzantine" or "pre-modern" are used instead, when referring to the Ottoman Empire. The touristic publications mention Ottoman invasions only. Ignoring the facts of recent history has eased the destruction of the cultural heritage belonging to the Ottoman period. This heritage has been destroyed deliberately in various periods. There are still a number of examples which have survived but only left exposed to the devastation of nature.

\section{Conclusion:}

When an independent Greek state was established in 1830, a Greek nation still had to emerge. The 18 th century Ottomans considered the Greeks as part of the Orthodox millet (or religious group), and the Greeks described themselves not as "Hellenes", but as "Romaioi", the Byzantine identification, the Turkish version of which was "Rum". The Greeks were widely but thinly distributed within the Ottoman Empire from the Adriatic to the Black Sea

\footnotetext{
${ }^{13}$ Türk Kültürüne Hizmet Vakfi, The Problem of Protection of the Ottoman Turkish Architectural Heritage in Greece, Istanbul, 1992. M. Kiel, "Notes on the History of Some Turkish Monuments in Thessaloniki and Their Founders," Balkan Studies, 2, (1970), 126-156; M. Kiel, "Observation on the History of Northern Greece during the Turkish Rule," Balkan Studies, 12 (1971), 415-462; Filiz Yenişehirlioğlu, Ottoman Architectural Works Outside Turkey, Ankara, Dışişleri Bakanlığı, 1989.
} 
coasts, and there were Greek merchant communities in many Western European cities.

Reminding the dichotomy between the Slavophiles and Westernisers in Tsarist Russia, the Orthodox church resented the mixture of classics and rationalism, introduced by Adamantios Korais, but nevertheless accepted the new concept of "Ellinismus", which reflected the whole Greek community in the world and Greek civilization. Irrespective of the divisions between the traditionalists and the westernizers and also between those who upheld a "pure Greek" language and who widely spoke the "demotic" variant, the Greeks seemed to agree on including within the Greek state all Greeks and lands considered by them to be Greek. This was the "Great Idea" (Megali Idea) that motivated many Greek intellectuals. The history of modern Greece is dominated by a process in which the Greek state expanded territorially while Ellinismos, as people and civilization, retreated.

From the point of view of the Greeks, the Turks "stood on the way". The latter were either killed or forced to flee. This was also the tragic fate of the Balkan, Crimean and the Caucasian Muslims in general. Before the Greek revolt (1821), a vast Muslim land existed from Bosnia to the eastern fringes of the Caucasus (and beyond), incorporating the Crimea and its hinterland in between. The Muslims were, not only the rulers there, but also constituted either the majority, plurality or sizable minorities. Millions were killed, and more millions were made refugees. The new states were established on the sufferings of the departed Muslims, mostly Turks, who had lived on those lands for five centuries or more. The Greek revolt, which had started with the murder of Ottoman officials, continued with ethnic cleansing because the Turks of Greece were on the way of a purely Greek state. Small pockets of Muslims and Turks remained, nevertheless, in various parts of the Balkans, such as in Westem Thrace.

Greece, still judging contemporary Turkey by the memories of the latter's Ottoman past, continues to ponder over real or mythologized losses. Greek failure to abandon the myth of ethnic homogeneity within its presentday frontiers is part of its new identity. Therefore, in Greek eyes, the Turks of Western Thrace are only a "Muslim minority", and Macedonians are no more that "Slavophone Greeks".

The Greek Government has taken some steps in 1991 to improve conditions in some areas for the Turkish minority. But important problems remain. Associations and schools cannot call themselves 'Turkish'. Turkishlanguage papers and books cannot be brought from Turkey into Western Thrace. Turkish TV is still jammed. Hundreds of Turks are deprived of their Greek citizenship. Police still harasses ethnic Turks. They are discriminated against in employment and in services. Their lands are confiscated. They face difficulties in education, in elections and in the selection of their own 
religious leaders. They cannot control their own charitable foundations. The Greek Government should abide by its obligations under international and national law to protect the Turkish minority's human rights.

There have been many individual complaints, demonstrations and appeals by Turks of Western Thrace to outside bodies such as the United Nations and the Council of Europe. While the official Greek attitude seems to be a deliberate policy of discrimination and assimilation, the situation has the potential of becoming more serious with the polarization of the communities in the whole of Western Thrace. Justice may be served and tension lowered when the Greek government abides by its obligations. 